\title{
Beauty and Appearance in Corporate Director Elections
}

\author{
Philipp Geiler, \\ EM Lyon Business School, 69134 Ecully, CS40203, France.
}

\section{Luc Renneboog*,}

Tilburg University, 5000 LE Tilburg, PO Box 90153, the Netherlands.

\section{Yang Zhao}

Newcastle University Business School, 5 Barrack Rd., Newcastle upon Tyne, NE1 4SE, UK.

\begin{abstract}
We study the role of facial appearance in corporate director (re-)elections by means of director photographs published in annual reports. We find that shareholders use inferences from facial appearance in corporate elections, as a better (higher rated) appearance measure of a director reduces voting dissent. These heuristics are based on perceived competence, trustworthiness, likability, and intelligence, but not on physical beauty. The results are valid for director re-elections but not for first appointment elections as in the latter cases, shareholders may not as yet be familiar with a director's looks. In firms with few institutional shareholders and more retail investors owning small equity stakes, the latter tend to rely more on facial appearance than institutional shareholders, presumably as institutions conduct more research on the director's background and performance, and consequently rely less on facial appearance. While female directors generally experience lower voting dissent, their facial appearance does not affect their elections results.
\end{abstract}

JEL Classification: G34, G39, G41

Keywords: Appearance; beauty; competence; corporate elections; gender; behavioral finance, annual general meeting, extraordinary meeting.

${ }^{*}$ Corresponding author.

E-mail addresses: Geiler@em-lyon.com (Philipp Geiler), Luc.Renneboog@uvt.nl (Luc Renneboog), Yang.Zhao@ncl.ac.uk (Yang Zhao). 


\section{Beauty and Appearance in Corporate Director Elections}

\section{Introduction}

The fact that an election candidate's facial appearance affects and even accurately predicts a political election's outcome has been shown by several studies (e.g. Todorov, Mandisodza, Goren, and Hall, 2005). Most research examines the effect of beauty on electoral success (Berggren et al., 2010; Benjamin and Shapiro, 2009; Leigh and Susilo, 2009; Olivola and Todorov, 2010; Rosar, Klein, and Becker, 2008). Berggren et al. (2010), for example, show that an increase in their measure of beauty by one standard deviation augments the votes in favor of a candidate by 20 percentage points. This finding holds for both male and female candidates and is unaffected by their education and occupation. While one would expect a rational voter to form an opinion about the candidate's suitability based on his or her political ideas, past track record, competence, or at least the program of the political party, the fact that beauty plays such an important role may surprise. The psychology literature on decisionmaking dedicates much attention to the dual-process decision framework, according to which individuals make instantaneous, unreflective, and effortless assessments of a candidate's appearance (the System 1 brain), and subsequently correct possible biases by consciously engaging in slow and effortful System 2 brain processes (Todorov et al., 2005). The strength of immediate decisions (System 1) can affect the processing of subsequent information, which may not (sufficiently) take place for a segment of the voters who thus mostly rely on first impressions (e.g. Bar et al., 2006; Willis and Todorov, 2006, Hall et al., 2009). Still, some, such as White, Kenrick, and Neuberg (2013), try to rationalize the voters' choice by stating that they rely on attractiveness as a cue to avoid electing leaders suffering from diseases. Others suggest that voters may simply favor good-looking candidates, as they enjoy watching them (Berggren, Jordahl, and Poutvara, 2010). It could also be possible that facial attraction is related to a set of traits, which are desirable for a job or position, but Graham, Harvey, and Puri (2017) reject this connection between facial attraction and superior performance.

In this paper, we turn to elections at the corporate level, namely the elections and the reelections of executive and non-executive directors, which are mandatory in the $\mathrm{UK}^{1}$, and wonder whether facial beauty is an advantage in director (re-)elections? Our basic hypothesis

\footnotetext{
${ }^{1}$ The UK Corporate Governance Code from 2016 (CGC, 2016: B.7.1., p. 15) states that: "All directors of FTSE 350 companies should be subject to annual election by shareholders. All other directors should be subject to election by shareholders at the first annual general meeting after their appointment, and to re-election thereafter at intervals of no more than three years. (...) The names of directors submitted for election or re-election should be accompanied by sufficient biographical details and any other relevant information to enable shareholders to take an informed decision on their election."
} 
is that facial beauty would not play a role because shareholders who vote on director ${ }^{2}$ (re)appointments can rely on information about the director's education and experience as well as about the firm's past performance, all of which is presented in the annual report and available prior to the (re-)election votes. However, even in a corporate context, there is some evidence that beauty plays a role: beauty is reflected in a corresponding premium in a top manager's remuneration (Hammermesh and Biddle, 1994; Graham et al., 2017), and the share price returns to news announcements made by CEOs with high facial attractiveness are higher (Halford and Hsu, 2014).

Even if facial attractiveness were to affect corporate elections, the question arises whether only beauty matters or also the appearance of competence? In the context of political elections, not only facial beauty but also perceived competence based on appearance augments electoral success (Hall et al., 2009; Todorov et al., 2005; Sussman et al., 2013). Perceived (appearancebased) competence positively affects the CEO selection and the size of his compensation contract (Graham et al., 2017). In addition to beauty and perceived competence, some studies test for other perceived traits (based on looks), such as leadership, trustworthiness, and intelligence, but this does not yield conclusive results (Berggren et al., 2010; Todorov et al., 2005).

We then ask the question whether facial appearance matters equally for male and female corporate directors? Some studies suggest that appearance may be the strongest predictor of political electoral success for female candidates, and that voters associate higher female attractiveness with more positive traits (Poutvaara, Jordahl, and Berggren, 2009; Nisbett and Wilson, 1977). Kaplan (1978) states that the 'attractiveness halo effect' only exists for female candidates.

We also examine whether facial appearance matters more for executive than for nonexecutive directors, because the former bear direct responsibility for the corporate results whereas the latter are mainly performing a governance and monitoring role.

Given that we can study both the first elections and re-elections of corporate directors, we ask whether facial appearance matters more in appointment elections than in re-elections? The reason for this conjecture is that, in the case of re-elections, shareholders have more information at their disposal: they should by then be aware of the corporate performance for which they can hold the directors partially responsible (or accountable), and have had the opportunity to learn more about the directors' education, experience, and track record because this information has by then appeared at least twice in annual reports. Furthermore, shareholders have been able to

\footnotetext{
${ }^{2}$ Throughout the paper, we use the UK terminology regarding board membership: a director is a member of the board and can be an executive or non-executive director. In the US, the term 'director' is usually reserved for a non-executive director.
} 
study the facial appearance more than once such that there is no 'first impression' effect anymore. Alternatively, facial appearance may be less important at first elections when shareholders may just follow the nomination committee's proposed candidate without relying on facial impressions, and thus give the candidate the benefit of doubt.

To our knowledge, this is the first study on the effects of facial appearance on voting dissent in corporate director elections. Notably, the situation is different from political voting processes, in that shareholders usually vote only on a single candidate for a director position. Still, as we observe the total number of favorable, against, and abstained votes for each individual director for each firm-year, we consider the abstained and against votes a disciplining device or a critical indicator (Grundfest, 2003). We perform an experiment whereby we have the director candidates' photos, which we hand-collected from the annual reports, rated on five dimensions (beauty, competence, trustworthiness, likability, and intelligence) on the basis of which we subsequently built our global appearance measure.

Our main findings can be summarized as follows: shareholders rely on inferences from facial appearance at corporate director elections as voting dissent decreases in a candidate's appearance (while controlling for corporate performance, other firm characteristics, and director education). When we dissect facial appearance into its five dimensions, we find that beauty does not affect voting dissent, but that directors who look more competent, trustworthy, likable, and intelligent receive more votes in their favor. The correlation between facial appearance and voting dissent holds for executive directors but not for non-executive directors. Shareholders rely more on facial appearance in the setting of director re-elections than of first appointment elections, which may reflect that they are more familiar with the looks of the directors who are up for re-election. Inferences from facial appearance matter more for investors holding small equity stakes, presumably as they have less time to conduct research on the past performance and background of directors. While female candidates experience in general less voting dissent than their male counterparts, their facial appearance (including beauty) does not affect their elections results.

\section{Institutional Facts and Data}

The setting for our study is the UK, which is characterized by a high level of corporate transparency regulation, a one-tier board model, mostly flat ownership structures, the oneshare-one-vote principle, and few cases of ownership pyramids or cascades (La Porta et al., 1999; ISS, 2007; Franks, Mayer, and Rossi, 2009). The UK Corporate Governance Code (CGC, 2016) demands a formal and transparent procedure for director appointments and a progressive 'refreshing' of the board (CGC, 2016: B.2). The search procedure for director candidates as well as their appointment should be conducted with the help of objective criteria and due regards to 
the benefits of diversity (CGC, 2016: B.2.4). The responsibility therefore typically resides with the nomination committee, which should be made up of a majority of independent nonexecutive members (CGC, 2016: B.2.1). Central to the CGC is that the board should undertake a formal evaluation of its own performance on a yearly basis (CGC, 2016: B.6). Subject to directors' satisfactory performance and commitment, the chairman can propose directors for appointment and re-election (CGC, 2016: B.7.1 \& B.7.2). The appointment of new directors of listed companies is subject to a shareholder vote at the first annual meeting after their proposed appointment. Incumbent directors of a FTSE 350 firm are up for reelection on a yearly basis at the annual general meeting. All other directors of listed firms are up for reelection at regular intervals of no more than three years. Specific rules apply to nonexecutives who have served for more than six years on the board: a particular rigorous review should then be undertaken of their position and functioning. Non-executives who served more than nine years on the board are subject to annual re-elections. According to a recent discussion paper on board (re)appointments, shareholders expressed a need for more information on individual directors as well as their individual corporate contributions for the purpose of re-elections (UK Board Succession Planning, 2015). While the UK Corporate Governance Code (2016) follows a 'comply or explain' approach that rendered boards with a substantial proportion of independent directors more attentive to shareholders interests (Guo and Masulis, 2012), the requirements of the FCA Listing Rule 9.8.6R(5) are binding and oblige the board to provide meticulous details on the procedures for board appointment. Furthermore, the Companies Act 2006 suggests that public companies should let shareholders individually vote on directors (Companies Act 2006: Ch. 1, 160(1)) and that shareholders should be given the power "to remove all or any of the directors at any time for any reason by ordinary majority vote" (Davies, 2015: 12). In sum, the UK Corporate Governance Code, the FCA Listing Rules, and the Companies Act make clear prescriptions on the process of director (re)appointments in terms of transparency, frequency, and shareholders involvement in the process.

We collect director election data (favorable, against, and abstained votes) from the Manifest database where we find information on 621 elections and re-elections for 144 male directors and 38 female directors over the period of 12 years (1996-2007). On average, we observe two votes per director over the entire sample period (Table 1). Frequently though, individuals serve simultaneously (and sequentially) on multiple boards and are therefore subject to a higher number of director elections: we observe a maximum of nine votes per individual in our sample. We distinguish also between first- and re-elections: First elections refer to all events where shareholders vote for the first time on a director's candidacy ( $26 \%$ of the sample) and which typically take place during the first annual meeting after the proposal to appoint the candidate to the board. We label all subsequent elections of a director as reelections. Following Gregory-Smith and Main (2014), we take as dependent variable the voting 
dissent, which is based on the sum of the non-positive votes (i.e. abstentions and against votes, both in percentages), divided by the favorable votes:

$$
\text { Dissent }=\frac{(\% \text { of non }- \text { positive votes })}{(1-\% \text { of non positive votes })}
$$

We give an example to illustrate the calculation of our dissent measure: $91.1 \%$ of the shareholders approve the re-election of R M Heard as a director in BPB plc at the annual general meeting on March 31, 1998. At the same time, $4.7 \%$ of the shareholder vote against this resolution and $4.3 \%$ opt for abstain. Hence, the calculation of our dissent measures gives: (4.7\% $+4.3 \%) / 91.1 \%=0.098$. Clearly, the higher the percentage of non-positive votes, the higher our dissent statistic becomes. In other words, the size of the dissent statistic reflects the level of dissent in a particular election. With a median dissent statistic of roughly 0.005 , most elections face a relatively low level of dissent consisting of relatively few against and abstained votes. ${ }^{3,4}$ When comparing the median with the reported mean of 0.026 , it becomes clear that the latter statistic is affected by a number of cases with a relatively high dissent: as a point in case, we observe a maximum dissent statistic of 0.422 for the re-election of Mr. S. Murfin as finance director and company secretary in Wyevale Garden Centres plc on April 30, 2003 with the non-positive votes amounting to roughly $29.7 \%$. Casting dissenting votes is likely to have a negative impact on the share price, as it could highlight a problem situated at the board level of the firm (Gregory-Smith and Main, 2014).

For all directors, we hand-collected their photographs from the annual reports at the time of the director election. As the director photographs are frequently re-used in the subsequent annual reports, we cannot track the impact of the evolution of facial appearance over time. We calculated an appearance score based on the ratings of directors' looks, whereby the raters were contacted by means of Amazon's Mechanical Turk, an online human intelligence platform, where we performed the experiment. Following Berggren et al. (2010), we asked the Mechanical Turk raters to evaluate the appearance of directors on a scale from 1 to 5 for each of five categories: beauty, competence, trustworthiness, likability, and intelligence, whereby five is the highest perceived attractiveness by category (see Appendix A). We provided the raters with these definitions: beauty stands for physical appearance or attractiveness of the person; competence for the ability to do something successfully or efficiently; trustworthiness for the ability to be relied on as honest or truthful; likability for being pleasant, friendly, and easy to like; and intelligence for the ability to acquire and apply knowledge and skills.

For each dimension of a director candidate's appearance, we collected the responses from at least five different raters. The raters were unaware of the purpose of this study, and did not

\footnotetext{
${ }^{3}$ Cai, Garner, and Walkling (2009: 2389) suggest that "even poorly performing directors typically receive over $90 \%$ of votes cast".

${ }^{4}$ Excluding the votes above $98 \%$ of approval shows an average against vote percentage of $2.0 \%$.
} 
know that they were evaluating the appearance of executive and non-executive directors. To avoid potential biases induced by the possibility that raters could recognize the directors (as some were e.g. CEOs of large firms who appear in the media), we excluded the director elections that took place over the past decade - our elections therefore cover the period 19962007. ${ }^{5}$ We have chosen raters that share the English-speaking cultural background of the directors; the raters stemmed from either the UK or the US. As a robustness test, in order to minimize the probability that the raters could recognize the directors, we restricted the raters to those with a US nationality. As experienced raters of Mechanical Turk can earn a 'Master' qualification, which reflects high reliability and accuracy in specific tasks across a variety of tasks, we only retained the raters with such a qualification. To make sure that raters have carefully read the instructions and questions before submitting their rating, we excluded the responses for which all five evaluations together (per rated person) were submitted within two seconds (i.e. $0.8 \%$ of the sample). ${ }^{6}$ The degree of rater agreement differs somewhat by category: while the consensus concerning likability is somewhat lower, we observe a stronger homogeneity in the ratings on intelligence and competence (see Table 1).

To compute the overall appearance score, we (i) scale each response by the rater's average response in the respective dimension (beauty, competence, trustworthiness, likability, intelligence) in order to correct for a potential bias introduced by an individual rater's attitude towards the dimension (in other words, we correct for the possibility that a rater persistently gives high or low scores on a specific appearance dimension), (ii) calculate the mean of the scaled responses on each dimension for each director, and (iii) also calculate the sum of the scores over all five dimensions for each director and then divide this sum by the maximum score of 25 in order to obtain the overall appearance score ranging from 0 to 1 . This overall appearance score (Mean, Scaled) ranges from 0.41 to 0.74 , with an average and median of 0.60 (Table 1). This table also includes the unscaled appearance scores (Mean, Raw is calculated by means of the average ratings that are not adjusted for individual rater's score levels) and the scores based on the median appearance score whereby the median is taken across raters by director and dimension and are presented as raw scores and scaled scores (adjusted for rating biases at the rater level). We apply the default set-up (Mean, Scaled) to the dimension scores that are also presented in Table 1.

As for the financial data, we use market capitalization (winsorized and log transformed in the regressions) and Tobin's Q (market capitalization divided by shareholders' equity,

\footnotetext{
${ }^{5}$ The raters were also explicitly asked whether they recognized him or her (by giving the candidate's name) when rating each subject. This was the case for two raters whose ratings were then excluded, thereby following the example of Benjamin and Shapiro (2009).

${ }^{6}$ As a robustness test, we excluded the responses submitted in less than five seconds, but this did not change the results.
} 
winsorized in the regressions) from Manifest, while all other data are from Datastream. The performance measure $\Delta \mathrm{Q}$ captures the change in Tobin's $\mathrm{Q}$ relative to the average of the previous three years.

The information on director gender, tenure (in years), and compensation come from Capital IQ and Manifest. To obtain our adjusted total compensation measure by director, we subtracted the average compensation of all directors for a given year and by industry from the director's compensation in a specific year, and did so for executive and non-executive directors separately. We also calculated the ratio of non-executive directors on the board as a measure of the degree of board monitoring. Variable definitions can be found in Appendix B. We also present a correlation matrix of the main variables in Appendix C. We do not detect a strong correlation between our explanatory variables (see Appendix C).

Insert Table 1 about Here

Subsequently, we put our hypotheses to a test, using the following regression model, which we estimate by means of (i) an OLS model with robust standard errors and with clustered standard errors at the company and the individual levels as robustness test, and (ii) a panel-data random-effects model:

$$
\begin{aligned}
\text { Dissent }_{i, t}=\alpha & +\beta_{1} \times \text { Appearance score }_{i}+\beta_{2} \times \text { Performance }_{j, t-1}+\beta_{3} \times \text { Tenure }_{i, t} \\
& +\beta_{4} \times \text { Total_Compensation }_{i, t}+\beta_{5} \\
& \times \text { Non }- \text { Executive Directors }(\%)_{j, t}+\beta_{6} \times \text { Market_Cap }_{j, t} \\
& +\beta_{7} \times \text { Industry FEs }+\beta_{8} \times \text { YearFEs }+\varepsilon_{i, j, t}
\end{aligned}
$$

\section{Results}

\subsection{Facial Appearance}

We present the relation between dissent and director appearance (and other control variables) in Table 2. Columns (1) - (4) exhibit the significantly negative effect of appearance on voting dissent for each of the four measures of overall facial appearance, described above. The parameter estimates suggest that a one standard deviation increase in the appearance score is associated with a decrease in voting dissent of about 0.007 , which is equivalent to a decrease in the likelihood of a negative vote of $26 \%$ on average. $^{7}$ Across all measures, the results are statistically significant at the $1 \%$ (or $5 \%$ ) level of confidence and support the idea that directors with better appearance are favored in corporate director elections. The models of Table 2 also

\footnotetext{
7 At the average level of voting dissent (0.026), there are $2.53 \%$ negative votes. A one standard deviation increase in overall appearance reduces dissent by 0.007 , which is equivalent to a decrease in the percentage of negative votes from $2.53 \%$ to $1.86 \%$.
} 
show that an improvement in performance relative to the previous three years (i.e., higher $\Delta \mathrm{Q}$ ) is significantly negatively associated with voting dissent (at the 5\%-level). Neither (board) tenure, which proxies for a first election (of a new director) or re-election, nor director compensation or the proportion of non-executives on the board are significantly related to the voting outcomes. We find that there is more dissent in larger companies, possibly due to the fact that the shareholder base is more dissipated. ${ }^{8}$ The results from our estimation with clustering standard errors at the individual level are similar to the results with clustering at the company level and to those obtained from random-effects panel data regressions (not shown). In sum, more 'attractive' facial appearance reduces dissent in corporate director elections.

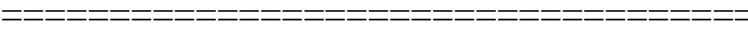

Insert Table 2 about Here

\subsection{Beauty and Perceived Competence}

We turn to the question which facial traits do shareholders (unconsciously) care about when voting in corporate director elections? We replace the appearance scores for the dimensions of facial appearance and show the corresponding results in Table $3 .{ }^{9}$ Most appearance dimensions, namely competence, trustworthiness, likability, and intelligence do affect voting: dissent is lower when the scores on these dimensions are higher. The exception is beauty, which is not statistically significant, suggesting that shareholders do not value the pure physical attractiveness of a director's appearance. We also document that higher adjusted total compensation is positively associated with dissent, which implies that excessive pay is frowned upon by shareholders. We summarize our findings from this table as follows: shareholders pay attention to those dimensions of appearance that they believe proxy for - whether or not rightly so - the traits required to perform the task of a director: competence, trustworthiness, and intelligence. In this sense, facial beauty appears not to be an advantage in corporate director elections, and perceived competence clearly dominates beauty with respect to its impact on shareholder voting behavior.

Insert Table 3 about Here

\footnotetext{
${ }^{8}$ We analyze the relationship between ownership structure and voting dissent in a reduced sample of companies for which ownership information is available. Block holdings of financial institutions, corporations and individuals are negatively, albeit not significantly, related with dissent (not shown). ${ }^{9}$ We do not include the five dimensions in one model in order to avoid possible multicollinearity: the maximum correlation between any two dimensions is 0.585 (see Appendix B).
} 


\subsection{Gender, Director Type, (Re-)Elections, and Institutional Ownership}

We examine the role of gender on voting dissent by including an indicator variable equal to one if the director candidate is female, as well as the interaction term between gender and appearance. The appearance of male directors is significantly negatively related to voting dissent (Column (1) of Table 4) with the size of the corresponding coefficient (-0.138) being in line with the one reported for all directors in column (1) of Table 2. The reported coefficient of 0.145 for the appearance effect of female directors is about as large, but is positively and significantly (at the $10 \%$ level) related to dissent. As the two parameter estimates largely cancel out, there is no effect of female directors' appearance on corporate director elections' voting dissent. This adds a twist to the idea that attractive looks result in more favorable real-world outcomes for individuals in most settings (Hammermersh, 2006).

Model (1) also shows that female directors generally face lower voting dissent as the estimate of the female dummy coefficient of -0.095 is negative, and (weakly) statistically significant. The reason why female directors experience less voting dissent may be that gender diversity at the board level is an important corporate goal and top female directors are still in short supply (Adams and Ferreira, 2009; Ferreira, 2010; CGC, 2016: B.2.4). A more detailed analysis by means of the five dimensions of appearance, such as beauty or competence, shows that these dimensions do not correlate with voting dissent for female directors (not tabulated). In sum, appearance matters for male directors in a context of corporate elections, but not for female directors.

Voting on executive director (re-)elections may attract more attention from shareholders because executives bear more responsibility for the firm's performance. Consequently, we split our sample and run our baseline regression on executive directors and non-executive directors separately. The corresponding results (Columns (2) and (3) of Table 4) indicate that the impact of appearance on dissent is mainly driven by the executive directors. Again, the results are qualitatively and quantitatively similar to those reported in our baseline regression (Table 2). This result suggests that facial appearance matters more for executive directors than for nonexecutive directors, presumably as the former have a higher responsibility with respect to corporate results.

In Columns (4) and (5), we partition the sample into first elections and re-elections. Contrary to our conjecture, appearance does not affect first elections, although shareholders have no or little information yet about these directors' performance especially when they are recruited from outside the firm, and shareholders then seem more prone to follow the nomination committee's recommendations and approve the candidate. In re-elections, appearance does have an impact on voting dissent. As time passes, shareholders are able to relate directors to past firm performance, but when they are more familiar with the directors, these directors' appearance then starts to matter more. A reason may be that shareholders are 
now ready to deviate from the nomination committee's recommendation, but still largely fail to process additional information to correct biases stemming from their first impressions (Todorov et al., 2005; Todorov and Uleman, 2003). In Column (6), we restrict our sample to only one re-election per director and company in order to focus on the cross-sectional dimension of the data and to rule out any concern about autocorrelation. The results for this restricted sample confirm that director appearance significantly reduces voting dissent.

Lastly, we investigate whether our results depend on shareholder type. It may be that institutional shareholders are more likely to conduct research, prior to the vote, on the quality of the candidates. Therefore, director appearance may be less likely to affect their voting decisions. Retail investors, in contrast, who primarily own only small share stakes may not analyze candidates' profiles and past performance in detail, which may entail that they use the appearance heuristic to proxy for the real competence and trustworthiness of the director. Therefore, we retest our baseline regression for the subsamples of firms with low institutional ownership (bottom half) and those with high institutional ownership (top half) in columns (7) and (8) of Table 4. We find that appearance is important for the firms in both subsamples, but the effect is stronger (and statistically significant) for companies with low institutional ownership, which suggests that inferences from facial appearance matter more for shareholders who are less likely to conduct research on director quality.

Insert Table 4 about Here

\subsection{Robustness Tests}

We perform the following robustness tests: First, we consider the candidates' level of education as an additional explanatory variable for voting outcome. Column (1) in Table 5 presents the corresponding results. The categorical variable education is equal to 1 for a director with a professional qualification or a university-level bachelor degree, 2 in case of a master degree, and 3 if the candidate has been awarded a doctoral degree. A candidate without a formal university degree is assigned a value of 0 . As we do not find a significant relation between a candidate's education and voting dissent, while overall appearance and the individual dimensions perceived competence and intelligence remain significant, we conclude that neither overall appearance, nor perceived competence or intelligence go hand in hand with the level of education.

Second, we investigate whether the relation between dissent, on the one hand, and appearance and its dimensions on the other, is non-linear by including higher order appearance variables. We do not find evidence that the relation is non-linear (not tabulated). 
Third, we re-estimate our baseline model using alternative dissent measures, such as (nonpositive votes)/(1-negative votes) (see Column (2)) and a measure where all abstained votes are excluded. Our results do not change.

Fourth, we re-estimate our base line model with different performance measures (e.g. including the current performance $(\mathrm{Q})$, and the change in $\mathrm{Q}$ relative from the past one-year average performance) and with a firm's accounting performance measure (ROA), but this has no material impact on our results (not tabulated).

Fifth, we measure the models clustering standard errors at the individual and company level and perform a random effects model. The corresponding results (Column (3) and (4)) confirm our baseline results. The results are also robust to including company and industry fixed effects, as well as time fixed effects.

Insert Table 5 about Here

\section{Conclusion}

By means of annual report photographs of corporate directors who are candidates for a board position or are up for re-election, we gather ratings of various dimensions of facial appearance (beauty, perceived competence, trustworthiness, likability, and intelligence) on the basis of which we construct an overall appearance measure. In line with studies on political elections (Berggren et al., 2010; Todorov et al., 2005), our results suggest that shareholders use inferences from facial appearance in corporate director elections. We find that directors with better (higher rated) appearance fare better in corporate director elections, as an increase in the measure of appearance by one standard deviation is associated with a decrease in voting dissent, equivalent to a decrease in the likelihood of negative votes of $26 \%$ on average. By examining the various dimensions of appearance, we reveal that facial beauty - in contrast to the case of political elections - does not play a role in director (re-)elections, but that perceived competence, trustworthiness, likability, and intelligence reduce voting dissent. This implies that shareholders regard director traits, such as competence, trustworthiness, and intelligence, which are all needed in the position of director, as important and that they use imperfect heuristics, namely whether these traits are perceived in the physical appearance of the directors, as proxies for the (real) traits. When we examine the gender-related effects of appearance on voting dissent, we find that appearance does not affect female director elections. Female candidates generally face less voting dissent than their male counterparts, presumably because companies and shareholders recognize the benefits of gender diversity at the board level and because top 
female directors are still in short supply (Adams and Ferreira, 2009; Ferreira, 2010; CGC, 2016: B.2.4). We also document that shareholders owning small equity stakes are more likely to rely on inferences from facial appearance than those holding large equity blocks, presumably because major blockholders perform more research on the directors' performance and background than small retail investors.

\section{Acknowledgments:}

The authors thank Margit Muenzer for providing valuable research assistance. We thank Panu Poutvaara for providing us with the questionnaires used in their research (Berggren et al., 2017).

\section{Funding:}

This research did not receive any specific grant from funding agencies in the public, commercial, or not-for-profit sector.

\section{References:}

Adams, R. and Ferreira, D. 2009. "Women in the boardroom and their impact on governance and performance", Journal of Financial Economics 94(2), 291-309.

Bar, M., Neta, M., \& Linz, H. 2006. "Very first impressions", Emotion, 6, 269-278.

Benjamin, D.J. and Shapiro, J. M. 2009. "Thin-Slice Forecasts of Gubernatorial Elections", Review of Economics and Statistics 91(33), 523-536.

Berggren, N., Jordahl, H. and Poutvaara, P. 2010. "The looks of a winner: Beauty and electoral success", Journal of Public Economics, 94(1-2), 8-15.

Berggren, N., Jordahl, H., and Poutvaara, P. 2017. "The Right Look: Conservative Politicians Look Better and Voters Reward It", Journal of Public Economics, 146, 79-86.

Cai, J., Garner, J.L., \& Walkling, R.A. 2009. "Electing Directors", Journal of Finance 64(5), 2389-2421.

Davies, Paul L., 2015. "Shareholders in the United Kingdom", European Corporate Governance Institute Law Working Paper No. 280, available at SSRN: https://ssrn.com/abstract=2557680

FCA Listing Rules, 2015, Financial Conduct Authority, available at: www.fca.org.uk.

Ferreira, D. "Board Diversity" in "Corporate Governance: A Synthesis of Theory, Research, and Practice", Anderson, R. and Baker, H.K. (eds.), John Wiley and Sons, 2010, 225-242.

Financial Reporting Council (FRC). 2003. The Combined Code on Corporate Governance, available at: http://www.ecgi.org/codes/documents/combined code final.pdf.

Financial Reporting Council (FRC). 2016. The UK Corporate Governance Code (April 2016), available at: www.frc.org.uk/Our-Work/Publications/Corporate-Governance/UKCorporate-Governance-Code-April-2016.pdf 
Franks, J., Mayer, C., and Rossi, S. 2009. "Ownership: Evolution and Regulation”, The Review of Financial Studies 22(10), 4009-4056.

Gregory-Smith, I. and Main, B. G. M. 2014. "Binding votes on executive remuneration", Unpublished Working Paper

Graham, J. R., Campbell, H. R., and Puri, M. 2017. "A Corporate Beauty Contest”, Management Science 63(9), 3044-3056.

Grundfest, J. M. 2003. "An Alternative Mechanism for Shareholder Participation in the Nomination and Election of Corporate Directors", Working Paper 274, Stanford Law School, 1-27.

Guo, L. \& Masulis, R.W. 2015. "Board Structure and Monitoring: New Evidence from CEO Turnovers", The Review of Financial Studies 28(10), 2770-2811.

Halford, J. T. and Hsu, S. H. C., 2014. "Beauty is Wealth: CEO Appearance and Shareholder Wealth", available at SSRN: https://ssrn.com/abstract=2357756 or http://dx.doi.org/10.2139/ssrn.2357756

Hall, C. C., Goren, A., Chaiken, S., and Todorov, A. "Shallow Cues with Deep Effect: Trait Judgments From Faces and Voting Decisions" in "The Political Psychology of Democratic Citizenship", Borgida, E., Federico, C.M. and Sullivan, J.L. (eds.), Oxford University Press, 2009, 73-99.

Hammermesh, D. S. 2006. "Changing looks and changing "discrimination": The beauty of economists", Economics Letters 93, 405-412.

Hammermesh, D. S. and Biddle, J. E. 1994. "Beauty and the Labor Market", The American Economic Review, 84(5), 1174-1194.

Hampel Report (Final), 2002. "Committee on Corporate Governance - Final Report", available at: http://www.ecgi.org/codes/code.php?code_id=130.

Institutional Shareholder Services (ISS). 2007. Proportionality between ownership and control in EU listed companies: External study commissioned by the European Commission. Available at http://www.ecgi.org/osov/documents/final_report_en.pdf

Kaplan, R.M. 1978. "Is beauty talent? Sex interaction in the attractiveness halo effect", Sex Roles 4(2), 195-204.

La Porta, R., Lopez-de-Silanes, F. and Shleifer, A. 1999. "Corporate ownership around the World", Journal of Finance 52: 1130-1150.

Leigh, A., and Susilo, T., 2009. "Is voting skin-deep? Estimating the effect of candidate ballot photographs on election outcomes”, Journal of Economic Psychology 30 (1), 61-70.

Nisbett, R.E. and T.D. Wilson 1977. "The Halo Effect: Evidence for Unconscious Alteration of Judgments", Journal of Personality and Social Psychology 35(4), 250-256.

Olivola, C.Y. and Todorov, A. 2010. "Elected in 100 miliseconds: Appearance-based trait inferences and voting”, Journal of Nonverbal Behavior, 34, 83-110. 
Poutvaara, P., Jordahl, H. and Berggren, N. 2009, "Faces of Politicians: Babyfacedness Predicts Inferred Competence but Not Electoral Success", Journal of Experimental Social Pschychology, 45(5), 1132-1135.

Rosar, U., Klein, M., and Beckers, T. 2008. “The frog pond beauty contest: Physical attractiveness and electoral success of the constitutency candidates at the North-Rhine Westphalia state election of 2005", European Journal of Political Research 47: 64-79.

Sussman, A. B., Petkova, K., and Todorov, A. 2013. "Competence ratings in US predict presidential election outcomes in Bulgaria", Journal of Experimental Social Psychology, $49,771-775$.

The UK Corporate Governance Code (CGC), 2016, Financial Reporting Council, available at: www.frc.org.uk.

Todorov, A., Mandisodza, A. N., Goren, A., and Hall, C. C. 2005. "Inferences of Competence from Faces Predict Election Outcomes", Science, 308(5728), 1623-1626.

Todorov, A., and Uleman, J. S. 2003. "The efficiency of binding spontaneous trait inferences to actor's faces", Journal of Experimental Social Psychology, 39, 549-562.

UK Board Succession Planning (Discussion Paper), 2015, Financial Reporting Council, available at: www.frc.org.uk.

White, A. E., Kenrick, D. T., and Neuberg, S. L. 2013. "Beauty at the Ballot Box: Disease Threats Predict Preferences for Physically Attractive Leaders", Psychological Science 24(12), 2429-2436.

Willis, J. and Todorov, A. 2006, "First impressions: making up your mind after $100 \mathrm{~ms}$ exposure to a face", Psychological Sciences 17, 592-598. 


\section{Table 1. Descriptive Statistics of the Main Variables}

This table shows descriptive statistics of the main variables. The corresponding list of variable definitions, including the calculation of the variables is presented in Appendix B. The data are from Boardex, Capital IQ, Datastream, Manifest, and from our own experiment.

\begin{tabular}{lrrrrrr}
\hline Variable & N & \multicolumn{1}{c}{ Mean } & \multicolumn{1}{c}{ SD } & \multicolumn{1}{c}{ Min } & \multicolumn{1}{c}{ Median } & Max \\
\hline No. elections/individual and company & 307 & 2.022 & 1.211 & 1 & 2 & 9 \\
Approval & 447 & 0.662 & 0.457 & 0 & 0.979 & 1 \\
Against & 447 & 0.011 & 0.024 & 0 & 0.003 & 0.173 \\
Abstain & 447 & 0.011 & 0.029 & 0 & 0.001 & 0.236 \\
Dissent & 447 & 0.026 & 0.059 & 0 & 0.005 & 0.422 \\
Appearance - beauty & 603 & 2.994 & 0.451 & 1.682 & 2.994 & 4.275 \\
Appearance - competence & 603 & 3.021 & 0.347 & 1.829 & 3.009 & 3.657 \\
Appearance - trustworthiness & 603 & 3.004 & 0.387 & 1.959 & 2.958 & 3.941 \\
Appearance - likability & 603 & 2.965 & 0.574 & 1.342 & 3.003 & 4.229 \\
Appearance - intelligence & 603 & 3.014 & 0.320 & 2.058 & 3.038 & 3.775 \\
Appearance (Mean, Scaled) & 603 & 0.600 & 0.054 & 0.406 & 0.604 & 0.741 \\
Appearance (Mean, Raw) & 603 & 0.673 & 0.061 & 0.464 & 0.672 & 0.824 \\
Appearance (Median, Scaled) & 603 & 0.599 & 0.057 & 0.403 & 0.601 & 0.750 \\
Appearance (Median, Raw) & 603 & 0.671 & 0.065 & 0.480 & 0.680 & 0.840 \\
Female (dummy) & 621 & 0.219 & 0.414 & 0 & 0 & 1 \\
$\Delta$ Q & 547 & 0.004 & 0.459 & -0.801 & -0.035 & 1.098 \\
Tobin's Q & 589 & 3.155 & 2.879 & 0.606 & 2.168 & 11.694 \\
Tenure (years) & 621 & 3.994 & 3.960 & 0 & 2.902 & 21.999 \\
Total compensation (adj.) & 591 & 0.289 & 0.962 & -0.652 & 0 & 1.886 \\
Non-executives (\%) & 621 & 54.9 & 15.9 & 0.00 & 54.5 & 92.9 \\
Market capitalization (in bn) & 589 & 3.257 & 5.559 & 0.062 & 0.897 & 22.763 \\
\hline
\end{tabular}




\section{Table 2. Overall Facial Appearance and Voting Dissent}

The table shows the effect of our facial appearance variable that is measured in four different ways: score based on (1) mean rating, adjusted for rater biases, (2) mean rating, but not adjusted (raw data), (3) median rating, adjusted for rater biases, and (4) median rating, not adjusted (raw data) of dissent in corporate director elections. The respective calculation methods are described in section 2 and in Appendix B. The dependent variable is the logarithm of voting dissent (the sum of the non-positive votes over the positive votes, both in percentages). The table shows the coefficients (standard error), as well as the significance of the results at the $10 \%, 5 \%$, or $1 \%$ level, denoted with ${ }^{*},{ }^{* *}$, and ${ }^{* * *}$, respectively. The data are from Capital IQ, Datastream, Manifest, and from our own experiment.

\begin{tabular}{|c|c|c|c|c|}
\hline & $(1)$ & $(2)$ & (3) & (4) \\
\hline Appearance (Mean, Scaled) & $\begin{array}{c}-0.127^{* *} \\
(0.052)\end{array}$ & & & \\
\hline Appearance (Mean, Raw) & & $\begin{array}{c}-0.120^{* * *} \\
(0.046)\end{array}$ & & \\
\hline Appearance (Median, Scaled) & & & $\begin{array}{c}-0.105^{\text {** }} \\
(0.046)\end{array}$ & \\
\hline Appearance (Median, Raw) & & & & $\begin{array}{c}-0.112^{* * * *} \\
(0.039)\end{array}$ \\
\hline$\Delta \mathrm{Q}$ & $\begin{array}{c}-0.008^{* *} \\
(0.004)\end{array}$ & $\begin{array}{c}-0.008^{* *} \\
(0.004)\end{array}$ & $\begin{array}{c}-0.008^{* *} \\
(0.004)\end{array}$ & $\begin{array}{c}-0.008^{* *} \\
(0.004)\end{array}$ \\
\hline Tenure & $\begin{array}{c}0.001 \\
(0.001)\end{array}$ & $\begin{array}{c}0.001 \\
(0.001)\end{array}$ & $\begin{array}{c}0.001 \\
(0.001)\end{array}$ & $\begin{array}{c}0.001 \\
(0.001)\end{array}$ \\
\hline Total compensation (adj.) & $\begin{array}{c}0.002 \\
(0.001)\end{array}$ & $\begin{array}{c}0.001 \\
(0.001)\end{array}$ & $\begin{array}{c}0.002 \\
(0.001)\end{array}$ & $\begin{array}{c}0.002 \\
(0.001)\end{array}$ \\
\hline Non-executives $(\%)$ & $\begin{array}{c}0.034 \\
(0.024)\end{array}$ & $\begin{array}{c}0.035 \\
(0.024)\end{array}$ & $\begin{array}{c}0.035 \\
(0.024)\end{array}$ & $\begin{array}{c}0.036 \\
(0.024)\end{array}$ \\
\hline (Log) market capitalization & $\begin{array}{l}0.005^{\text {** }} \\
(0.002)\end{array}$ & $\begin{array}{l}0.005^{* *} \\
(0.002)\end{array}$ & $\begin{array}{l}0.005^{* *} \\
(0.002)\end{array}$ & $\begin{array}{l}0.005^{* *} \\
(0.002)\end{array}$ \\
\hline Constant & $\begin{array}{c}0.017 \\
(0.035)\end{array}$ & $\begin{array}{c}0.021 \\
(0.034)\end{array}$ & $\begin{array}{c}0.007 \\
(0.033)\end{array}$ & $\begin{array}{c}0.016 \\
(0.031)\end{array}$ \\
\hline Industry dummies & Yes & Yes & Yes & Yes \\
\hline $\begin{array}{l}\text { Year dummies } \\
\text { Adi R-Squared }\end{array}$ & $\frac{\text { Yes }}{0163}$ & Yes & Yes & Yes \\
\hline $\begin{array}{l}\text { Adj. R-Squared } \\
\mathrm{N}\end{array}$ & $\begin{array}{c}0.163 \\
414\end{array}$ & $\begin{array}{c}0.165 \\
414\end{array}$ & $\begin{array}{c}0.160 \\
414\end{array}$ & 414 \\
\hline
\end{tabular}




\section{Table 3. The Dimensions of Appearance and Voting Dissent}

The table shows the effect of the five appearance dimensions ((1) beauty, (2) competence, (3) trustworthiness, (4) likability, and (5) intelligence) on dissent in corporate director elections. The dependent variable is the logarithm of voting dissent. The table shows the coefficients (standard errors), as well as the significance of the results at the $10 \%, 5 \%$, or $1 \%$ level, denoted with ****, and ${ }^{* * *}$, respectively. The data are from Capital IQ, Datastream, Manifest, and from our own experiment.

\begin{tabular}{|c|c|c|c|c|c|}
\hline & $(1)$ & $(2)$ & (3) & (4) & $(5)$ \\
\hline Appearance - beauty & $\begin{array}{l}-0.005 \\
(0.006)\end{array}$ & & & & \\
\hline Appearance - competence & & $\begin{array}{l}-0.013^{*} \\
(0.007)\end{array}$ & & & \\
\hline Appearance - trustworthiness & & & $\begin{array}{l}-0.013^{*} \\
(0.007)\end{array}$ & & \\
\hline Appearance - likability & & & & $\begin{array}{l}-0.012^{*} \\
(0.007)\end{array}$ & \\
\hline Appearance - intelligence & & & & & $\begin{array}{l}-0.015^{*} \\
(0.009)\end{array}$ \\
\hline$\Delta \mathrm{Q}$ & $\begin{array}{c}-0.008^{* *} \\
(0.004)\end{array}$ & $\begin{array}{c}-0.008^{* *} \\
(0.004)\end{array}$ & $\begin{array}{c}-0.008^{* *} \\
(0.004)\end{array}$ & $\begin{array}{c}-0.008^{* *} \\
(0.004)\end{array}$ & $\begin{array}{c}-0.008^{* *} \\
(0.004)\end{array}$ \\
\hline Tenure & $\begin{array}{c}0.001 \\
(0.001)\end{array}$ & $\begin{array}{c}0.002 \\
(0.001)\end{array}$ & $\begin{array}{c}0.001 \\
(0.001)\end{array}$ & $\begin{array}{c}0.001 \\
(0.001)\end{array}$ & $\begin{array}{c}0.002 \\
(0.001)\end{array}$ \\
\hline Total compensation (adj.) & $\begin{array}{c}0.002^{*} \\
(0.001)\end{array}$ & $\begin{array}{c}0.002^{*} \\
(0.001)\end{array}$ & $\begin{array}{c}0.002 \\
(0.001)\end{array}$ & $\begin{array}{c}0.001 \\
(0.001)\end{array}$ & $\begin{array}{l}0.002^{*} \\
(0.001)\end{array}$ \\
\hline Non-executives (\%) & $\begin{array}{c}0.034 \\
(0.024)\end{array}$ & $\begin{array}{c}0.036 \\
(0.024)\end{array}$ & $\begin{array}{c}0.034 \\
(0.024)\end{array}$ & $\begin{array}{c}0.031 \\
(0.025)\end{array}$ & $\begin{array}{c}0.038 \\
(0.024)\end{array}$ \\
\hline (Log) market capitalization & $\begin{array}{l}0.005^{* *} \\
(0.002)\end{array}$ & $\begin{array}{l}0.005^{* *} \\
(0.002)\end{array}$ & $\begin{array}{l}0.005^{* *} \\
(0.002)\end{array}$ & $\begin{array}{l}0.005^{* *} \\
(0.002)\end{array}$ & $\begin{array}{l}0.005^{* *} \\
(0.002)\end{array}$ \\
\hline Constant & $\begin{array}{l}-0.033 \\
(0.031)\end{array}$ & $\begin{array}{l}-0.052^{*} \\
(0.029)\end{array}$ & $\begin{array}{l}-0.015 \\
(0.030)\end{array}$ & $\begin{array}{l}-0.016 \\
(0.031)\end{array}$ & $\begin{array}{l}-0.010 \\
(0.027)\end{array}$ \\
\hline Industry dummies & Yes & Yes & Yes & Yes & Yes \\
\hline Year dummies & Yes & Yes & Yes & Yes & Yes \\
\hline Adj. R-Squared & 0.151 & 0.155 & 0.156 & 0.162 & 0.156 \\
\hline $\mathrm{N}$ & 414 & 414 & 414 & 414 & 414 \\
\hline
\end{tabular}


Table 4. Gender, Director Type, (Re-)Elections, and Institutional Ownership

The dependent variable is the logarithm of voting dissent on which the impact of gender is estimated in column (1). The table shows subsample analyses on the impact of appearance on executive versus nonexecutive directors (columns (2) and (3)), on first elections versus re-elections (columns (4) and (5)) and on institutional ownership (columns (7) and (8)). The table shows the coefficients (standard errors), as well as the significance of the results at the $10 \%, 5 \%$, or $1 \%$ level, denoted with ${ }^{* * *}$, and $^{* * *}$, respectively. The data are from Capital IQ, Datastream, Manifest, and from our own experiment.

\begin{tabular}{|c|c|c|c|c|c|c|c|c|}
\hline & $(1)$ & $(2)$ & (3) & $(4)$ & $(5)$ & $(6)$ & (7) & $(8)$ \\
\hline & $\begin{array}{c}\text { Focus on } \\
\text { Female }\end{array}$ & $\begin{array}{c}\text { Executives } \\
\text { only }\end{array}$ & $\begin{array}{l}\text { Non- } \\
\text { executives } \\
\text { only }\end{array}$ & $\begin{array}{c}\text { First } \\
\text { elections } \\
\text { only }\end{array}$ & $\begin{array}{c}\text { Re- } \\
\text { elections } \\
\text { only }\end{array}$ & $\begin{array}{l}\text { One re- } \\
\text { election per } \\
\text { individual } \\
\& \text { company }\end{array}$ & $\begin{array}{c}\text { Low } \\
\text { institutional } \\
\text { ownership }\end{array}$ & $\begin{array}{c}\text { High } \\
\text { institutional } \\
\text { ownership }\end{array}$ \\
\hline Appearance & $\begin{array}{c}-0.138^{* *} \\
(0.066)\end{array}$ & $\begin{array}{c}-0.134^{* *} \\
(0.056)\end{array}$ & $\begin{array}{c}-0.194 \\
(0.164)\end{array}$ & $\begin{array}{c}0.030 \\
(0.084)\end{array}$ & $\begin{array}{c}-0.168^{* * *} \\
(0.061)\end{array}$ & $\begin{array}{l}-0.148^{*} \\
(0.085)\end{array}$ & $\begin{array}{l}-0.179^{*} \\
(0.101)\end{array}$ & $\begin{array}{c}-0.057 \\
(0.049)\end{array}$ \\
\hline Appearance $*$ Female & $\begin{array}{c}0.145^{*} \\
(0.089)\end{array}$ & & & & & & & \\
\hline Female & $\begin{array}{l}-0.095^{*} \\
(0.057)\end{array}$ & & & & & & & \\
\hline$\Delta \mathrm{Q}$ & $\begin{array}{c}-0.008^{* *} \\
(0.004)\end{array}$ & $\begin{array}{l}-0.008^{*} \\
(0.005)\end{array}$ & $\begin{array}{l}-0.010^{*} \\
(0.005)\end{array}$ & $\begin{array}{c}-0.004 \\
(0.004)\end{array}$ & $\begin{array}{c}-0.009^{*} \\
(0.005)\end{array}$ & $\begin{array}{l}-0.011^{*} \\
(0.006)\end{array}$ & $\begin{array}{l}-0.015 \\
(0.009)\end{array}$ & $\begin{array}{l}-0.006^{*} \\
(0.003)\end{array}$ \\
\hline Tenure & $\begin{array}{c}0.001 \\
(0.001)\end{array}$ & $\begin{array}{c}0.002 \\
(0.001)\end{array}$ & $\begin{array}{c}0.002 \\
(0.002)\end{array}$ & $\begin{array}{c}-0.004 \\
(0.010)\end{array}$ & $\begin{array}{c}0.001 \\
(0.001)\end{array}$ & $\begin{array}{c}0.001 \\
(0.002)\end{array}$ & $\begin{array}{c}0.003^{*} \\
(0.001)\end{array}$ & $\begin{array}{c}0.001 \\
(0.001)\end{array}$ \\
\hline Total compensation (adj.) & $\begin{array}{c}0.001 \\
(0.001)\end{array}$ & $\begin{array}{c}0.002 \\
(0.001)\end{array}$ & $\begin{array}{c}0.004 \\
(0.003)\end{array}$ & $\begin{array}{c}0.001 \\
(0.001)\end{array}$ & $\begin{array}{c}0.003 \\
(0.004)\end{array}$ & $\begin{array}{c}0.004 \\
(0.005)\end{array}$ & $\begin{array}{c}0.002^{*} \\
(0.001)\end{array}$ & $\begin{array}{c}0.001 \\
(0.002)\end{array}$ \\
\hline Non-executives (\%) & $\begin{array}{c}0.035 \\
(0.024)\end{array}$ & $\begin{array}{c}0.025 \\
(0.035)\end{array}$ & $\begin{array}{c}0.023 \\
(0.037)\end{array}$ & $\begin{array}{c}0.052 \\
(0.057)\end{array}$ & $\begin{array}{c}0.025 \\
(0.027)\end{array}$ & $\begin{array}{l}-0.003 \\
(0.037)\end{array}$ & $\begin{array}{c}0.029 \\
(0.040)\end{array}$ & $\begin{array}{c}0.013 \\
(0.029)\end{array}$ \\
\hline (Log) market capitalization & $\begin{array}{l}0.005^{* *} \\
(0.002)\end{array}$ & $\begin{array}{l}0.006^{* *} \\
(0.003)\end{array}$ & $\begin{array}{c}0.004 \\
(0.004)\end{array}$ & $\begin{array}{l}0.009^{* *} \\
(0.004)\end{array}$ & $\begin{array}{c}0.004 \\
(0.003)\end{array}$ & $\begin{array}{c}0.007^{*} \\
(0.004)\end{array}$ & $\begin{array}{c}0.005 \\
(0.004)\end{array}$ & $\begin{array}{l}0.005^{* *} \\
(0.003)\end{array}$ \\
\hline Constant & $\begin{array}{c}0.023 \\
(0.040) \\
\end{array}$ & $\begin{array}{c}0.002 \\
(0.035) \\
\end{array}$ & $\begin{array}{c}0.068 \\
(0.141) \\
\end{array}$ & $\begin{array}{c}-0.174^{* *} \\
(0.085)\end{array}$ & $\begin{array}{c}0.038 \\
(0.038) \\
\end{array}$ & $\begin{array}{c}-0.007 \\
(0.069)\end{array}$ & $\begin{array}{l}-0.026 \\
(0.050)\end{array}$ & $\begin{array}{c}-0.032 \\
(0.049)\end{array}$ \\
\hline Industry dummies & Yes & Yes & Yes & Yes & Yes & Yes & Yes & Yes \\
\hline Year dummies & Yes & Yes & Yes & Yes & Yes & Yes & Yes & Yes \\
\hline Adj. R-Squared & 0.167 & 0.192 & 0.192 & 0.273 & 0.168 & 0.272 & 0.251 & 0.193 \\
\hline $\mathrm{N}$ & 414 & 304 & 110 & 107 & 307 & 138 & 173 & 242 \\
\hline
\end{tabular}


Table 5. Education, Alternative Measures, Non-linearity, and Random-effects Model

The table shows the coefficients (standard errors), as well as the significance of the results at the $10 \%$, $5 \%$, or $1 \%$ level, denoted with ${ }^{*},{ }^{* *}$, and ${ }^{* * *}$, respectively. The data are from Boardex, Capital IQ, Datastream, Manifest, and from our own experiment.

\begin{tabular}{lcccc}
\hline & $(1)$ & $(2)$ & $(3)$ & $(4)$ \\
\hline Eppearance & Education & $\begin{array}{c}\text { Alternative } \\
\text { dissent } \\
\text { measure }\end{array}$ & $\begin{array}{c}\text { Std E cluster } \\
\text { company \& } \\
\text { individual }\end{array}$ & $\begin{array}{c}\text { Random- } \\
\text { effects }\end{array}$ \\
\hline Education & $-0.123^{* *}$ & $-0.109^{* *}$ & $-0.127^{*}$ & $-0.127^{* *}$ \\
& $(0.052)$ & $(0.046)$ & $(0.065)$ & $(0.050)$ \\
$\Delta$ Q & -0.009 & & & \\
Tenure & $(0.010)$ & & & \\
& $-0.009^{* *}$ & $-0.007^{* *}$ & $-0.008^{* * *}$ & $-0.008^{*}$ \\
Total compensation (adj.) & $(0.004)$ & $(0.003)$ & $(0.003)$ & $(0.005)$ \\
Non-executives (\%) & 0.001 & 0.001 & 0.001 & $0.001^{*}$ \\
& $(0.001)$ & $(0.001)$ & $(0.001)$ & $(0.001)$ \\
(Log) market capitalization & 0.001 & 0.001 & 0.002 & 0.002 \\
Constant & $(0.001)$ & $(0.001)$ & $(0.001)$ & $(0.001)$ \\
& 0.034 & 0.031 & 0.034 & 0.034 \\
Industry dummies & $(0.024)$ & $(0.021)$ & $(0.028)$ & $(0.024)$ \\
Year dummies & $0.005^{* * *}$ & $0.005^{* * *}$ & $0.005^{* *}$ & $0.005^{* * *}$ \\
\hline Adj. R-Squared & $(0.002)$ & $(0.002)$ & $(0.003)$ & $(0.002)$ \\
N & -0.015 & 0.014 & 0.017 & -0.020 \\
& $(0.031)$ & $(0.031)$ & $(0.038)$ & $(0.039)$ \\
\hline
\end{tabular}




\section{Appendix A. Amazon Mechanical Turk Experiment}

We conduct our appearance experiment on Amazon Mechanical Turk. The raters are asked the list of questions presented below. Raters judge appearance based on a director's photo extracted from the annual report. Responses are recorded on a 5-point Likert scale, ranging from 1 (worst) to 5 (best).

\begin{tabular}{ll}
\hline $\begin{array}{l}\text { Appearance } \\
\text { dimension }\end{array}$ & Question \\
\hline Beauty & $\begin{array}{l}\text { What is your evaluation of the physical appearance or attractiveness } \\
\text { of this person? }\end{array}$ \\
Competence & $\begin{array}{l}\text { What is your evaluation of the competence of this person? } \\
\text { (Competence: the ability to do something successfully or efficiently) }\end{array}$ \\
Trustworthiness & $\begin{array}{l}\text { What is your evaluation of the trustworthiness of this person? } \\
\text { (Trustworthiness: the ability to be relied on as honest or truthful) }\end{array}$ \\
Likability & $\begin{array}{l}\text { What is your evaluation of the likability of this person? } \\
\text { (Likability: being pleasant, friendly and easy to like) }\end{array}$ \\
Intelligence & $\begin{array}{l}\text { What is your evaluation of the intelligence of this person? } \\
\text { (Intelligence: the ability to acquire and apply knowledge and skills) }\end{array}$ \\
\hline
\end{tabular}

\section{Figure 1 Exemplary Screenshot from Raters' Evaluations Conducted on Mechanical Turk.}

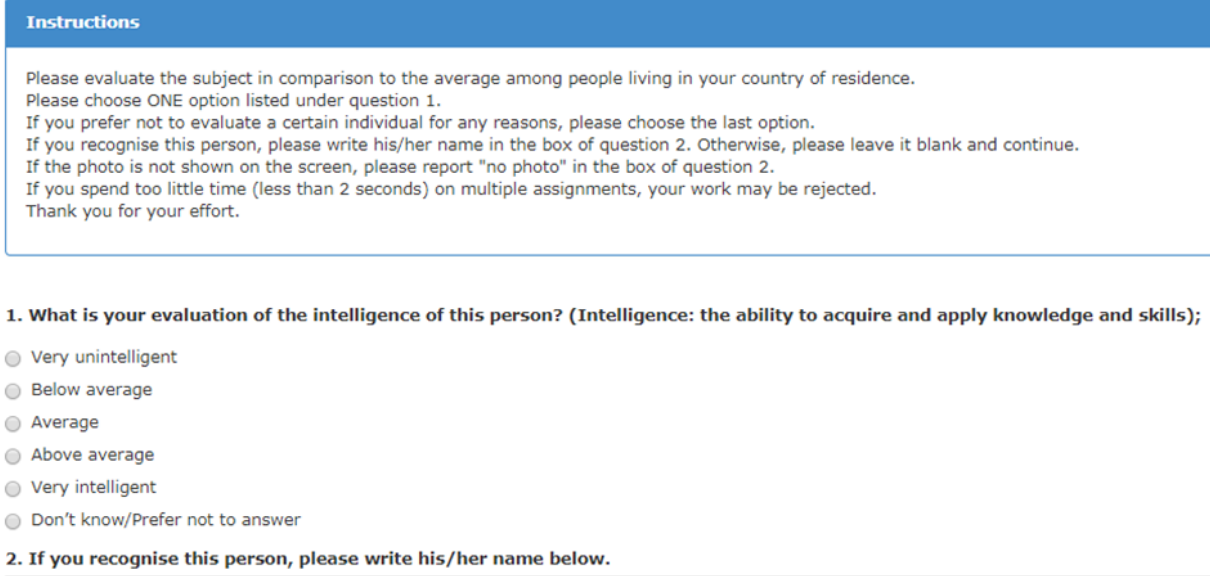




\section{Appendix B. Variable Definitions}

\begin{tabular}{|c|c|c|}
\hline Variables & Definition & Source \\
\hline \multicolumn{3}{|l|}{ Voting } \\
\hline Dissent & $\begin{array}{l}\text { The percentage of non-positive (against and abstained) } \\
\text { votes, divided by the percentage of approval votes. }\end{array}$ & Manifest \\
\hline \multicolumn{3}{|l|}{ Appearance measures } \\
\hline Appearance (Mean, Scaled) & $\begin{array}{l}\text { The sum of the mean values of the five appearance- } \\
\text { dimensions (beauty, competence, trustworthiness, } \\
\text { likability, and intelligence), each of which has been } \\
\text { scaled by rater average rating. This sum is then divided } \\
\text { by } 25 \text { (the maximum cumulative rating). }\end{array}$ & $\begin{array}{l}\text { Experiment } \\
\text { (Mechanical Turk) }\end{array}$ \\
\hline Appearance (Mean, Raw) & $\begin{array}{l}\text { The sum of the mean values of the five appearance- } \\
\text { dimensions, each of which has not been scaled by rater } \\
\text { average rating. This sum is then divided by } 25 \text { (the } \\
\text { maximum cumulative rating) }\end{array}$ & $\begin{array}{l}\text { Experiment } \\
\text { (Mechanical Turk) }\end{array}$ \\
\hline Appearance (Median, Scaled) & $\begin{array}{l}\text { The sum of the median values of the five appearance- } \\
\text { dimensions, each of which has been scaled by rater } \\
\text { average rating. This sum is then divided by } 25 \text { (the } \\
\text { maximum cumulative rating). }\end{array}$ & $\begin{array}{l}\text { Experiment } \\
\text { (Mechanical Turk) }\end{array}$ \\
\hline Appearance (Median, Raw) & $\begin{array}{l}\text { The sum of the median values of the five appearance- } \\
\text { dimensions, each of which has not been scaled by rater } \\
\text { average rating. This sum is then divided by } 25 \text { (the } \\
\text { maximum cumulative rating). }\end{array}$ & $\begin{array}{l}\text { Experiment } \\
\text { (Mechanical Turk) }\end{array}$ \\
\hline Appearance - Beauty & $\begin{array}{l}\text { The mean rating of the dimension Beauty, scaled by } \\
\text { rater average rating. }\end{array}$ & Mechanical Turk \\
\hline Appearance - Competence & $\begin{array}{l}\text { The mean rating of the dimension Competence, scaled } \\
\text { by rater average rating. }\end{array}$ & Mechanical Turk \\
\hline Appearance - Trustworthiness & $\begin{array}{l}\text { The mean rating of the dimension Trustworthiness, } \\
\text { scaled by rater average rating. }\end{array}$ & Mechanical Turk \\
\hline Appearance - Likability & $\begin{array}{l}\text { The mean rating of the dimension Likability, scaled by } \\
\text { rater average rating. }\end{array}$ & Mechanical Turk \\
\hline Appearance - Intelligence & $\begin{array}{l}\text { The mean rating of the dimension Intelligence, scaled } \\
\text { by rater average rating. }\end{array}$ & Mechanical Turk \\
\hline \multicolumn{3}{|l|}{ Performance } \\
\hline$\Delta \mathrm{Q}$ & $\begin{array}{l}\text { Change in Tobin's Q relative to the average of the } \\
\text { previous three years. }\end{array}$ & Datastream \\
\hline \multicolumn{3}{|l|}{ Director traits } \\
\hline Tenure & $\begin{array}{l}\text { The number of years a director serves in his current } \\
\text { (board) position. }\end{array}$ & CapitalIQ, Manifest \\
\hline Total compensation (adj.) & $\begin{array}{l}\text { An executive (non-executive) director's annual total } \\
\text { compensation minus the (median) total compensation of } \\
\text { other executive (non-executive) directors of the same } \\
\text { industry and year, standardized by the latter. }\end{array}$ & CapitalIQ, Manifest \\
\hline Female & $\begin{array}{l}\text { A binary variable that equals } 1 \text { in case of a female } \\
\text { director and } 0 \text { for a male director. }\end{array}$ & CapitalIQ, Manifest \\
\hline Education & $\begin{array}{l}\text { A categorical variable }(0-3) \text { with a higher value for } \\
\text { higher level of education: } 1 \text { if director has a } \\
\text { professional or university-level BA/BSc degree, } 2 \text { for a } \\
\text { MA/MSc degree, and } 3 \text { for a PhD. A director without a } \\
\text { formal university degree is assigned a value of } 0 \text {. }\end{array}$ & CapitalIQ, Manifest \\
\hline \multicolumn{3}{|l|}{ Firm characteristics } \\
\hline Non-executives (\%) & $\begin{array}{l}\text { The percentage of non-executive directors serving on } \\
\text { the board (the denominator is the total number of } \\
\text { directors on the board). }\end{array}$ & CapitalIQ, Manifest \\
\hline Market capitalization & $\begin{array}{l}\text { The market value of equity; the number of shares } \\
\text { outstanding multiplied with the share price. }\end{array}$ & CapitalIQ, Manifest \\
\hline
\end{tabular}


Appendix C. Correlation Matrix

\begin{tabular}{|c|c|c|c|c|c|c|c|c|c|c|c|c|}
\hline & & 1 & 2 & 3 & 4 & 5 & 6 & 7 & 8 & 9 & 10 & 11 \\
\hline 1 & Appearance (Mean, Scaled) & 1.000 & & & & & & & & & & \\
\hline 2 & Appearance - Beauty & 0.570 & 1.000 & & & & & & & & & \\
\hline 3 & Appearance-Competence & 0.679 & 0.293 & 1.000 & & & & & & & & \\
\hline 4 & Appearance - Trustworthiness & 0.731 & 0.162 & 0.333 & 1.000 & & & & & & & \\
\hline 5 & Appearance - Likability & 0.735 & 0.142 & 0.331 & 0.585 & 1.000 & & & & & & \\
\hline 6 & Appearance - Intelligence & 0.515 & 0.256 & 0.399 & 0.258 & 0.057 & 1.000 & & & & & \\
\hline 7 & $\Delta \mathrm{Q}$ & -0.038 & 0.028 & -0.029 & -0.076 & -0.054 & 0.019 & 1.000 & & & & \\
\hline 8 & Tenure & 0.015 & -0.038 & 0.087 & -0.047 & -0.002 & 0.083 & -0.028 & 1.000 & & & \\
\hline 9 & Total compensation (adj.) & 0.060 & 0.091 & 0.168 & -0.015 & -0.103 & 0.151 & 0.025 & -0.038 & 1.000 & & \\
\hline 10 & Non-executives (\%) & -0.019 & -0.018 & 0.059 & 0.009 & -0.126 & 0.099 & 0.068 & -0.062 & 0.277 & 1.000 & \\
\hline 11 & (Log) market capitalization & 0.014 & 0.034 & 0.128 & -0.031 & -0.101 & 0.095 & 0.013 & -0.094 & 0.487 & 0.308 & 1.000 \\
\hline
\end{tabular}

